\title{
普通鋳鉄切削に現われる超硬合金工具の損傷*
}

\author{
長 富 修 吉** 大草喜太雄**

\section{On the Failure of Cemented Carbide Tool appearing when Plain Cast Iron is cut}

\section{Shükichi NAGATOMI and Kitao ŌKUSA}

We observed the tool failure of three different kinds of cemented carbide tool in cutting plain cast iron. Weld was created at low speed on any tool, and some different types of tool failure were found at higher speed, that is, the tool with fine WC showed a rectangular type flank wear with deep crater and the coarse showed a triangular type with shallow crater. It being difficult to get the preferable rectangular type by cuttring such brittle cast iron, it is desirable that abnormal chipping does not appear. In this respect, the grade with both fine and coarse grains was preferable to the others.

Among the other factors affecting the failure, it was found that too small feed and relief angle accelerated the flank wear.

\section{1. 緒言}

との報告は軟質鋳鉄の代表として普通鋳鉄をとりあ， げ, 乙れ起 $\mathrm{G}_{1}, \mathrm{G}_{2}$, 米国 $\mathrm{K}$ 社品の 3 種の鋳鉄切削用超 硬合金材種起用にて工具材質, 削り速度, 送り, 切込, 逃げ角などの損㑺に及济影響を調べをものである.

\section{2. 被削材の特性}

実験に用いた普通鋳鉄の形状々直径 $200 \mathrm{~mm}$, 長さ $1000 \mathrm{~mm}$ の筒で, その化学成分, 機械的性質は Table 1 K示したよらなものである。この被削材は Photo. 1 の顕徽鏡組織に見るよらにパーライト組織 も少々あるが, 可成りの量のフェライトと片状黒鉛よ り成り立つている学め，これらの軟質な組成要素を含 まぬパーライト鋳鉄やミーハナイト鋳鉄よりす硬さ， 抗張力が低く, その上この図に見るようにピンホール 状の小孔が存在している. これらの理由のために, そ の切り疦は抗張力の高的前述の高級鋳鉄よりもいちじ るしく細からのである. Photo. 2 にその比較例者示 した.

Table. 1.

\begin{tabular}{c|c|c|c|c|c|c}
\hline \multicolumn{3}{c|}{ Composition (\%) } & \multicolumn{2}{c}{ Mechanical properties } \\
\hline $\mathrm{C}$ & $\mathrm{Si}$ & $\mathrm{Mn}$ & $\mathrm{P}$ & $\mathrm{S}$ & $\begin{array}{c}\text { Brinell } \\
\text { hardness }\end{array}$ & $\begin{array}{c}\text { Tensile } \\
\text { strength } \\
\left(\mathrm{kg} / \mathrm{mm}^{2}\right)\end{array}$ \\
\hline 3.18 & 1.58 & 0.50 & 0.09 & 0.10 & 150 & 12 \\
\hline
\end{tabular}

* 原秥受付 昭和 31 年 6 月 15 日

** タンガロイ工業株式会社

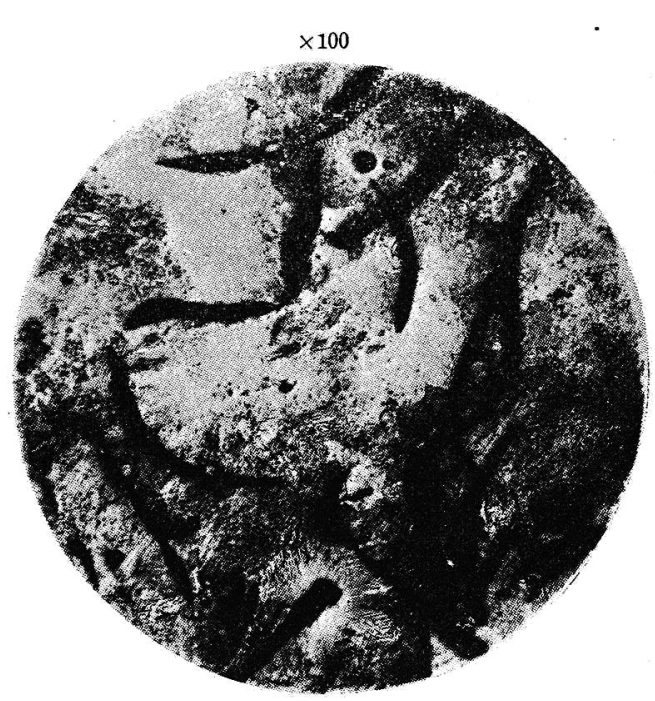

Photo. 1.

\section{3. 実 験 条 件}

Table 2 のような 3 種の工具材質を用い, Table 3 の実験種類を行つた。

\section{4. 鑄鉄切削に現机る基本的な損傷の種類}

この報告で損伤種類を表わすためと特別な用語を用 いるが、その詳細は文献に譲り，ととでは本報告に関 係あるものについて簡単に実例孛あげて説明する.

超硬工具の損偒原因には超硬合金材質や接着物が小 片となつて欠ける, すねわち, チッピング現象を起こ し，これが工具と切り属，被削材の間に㚘まつて高圧 
$\times 3$

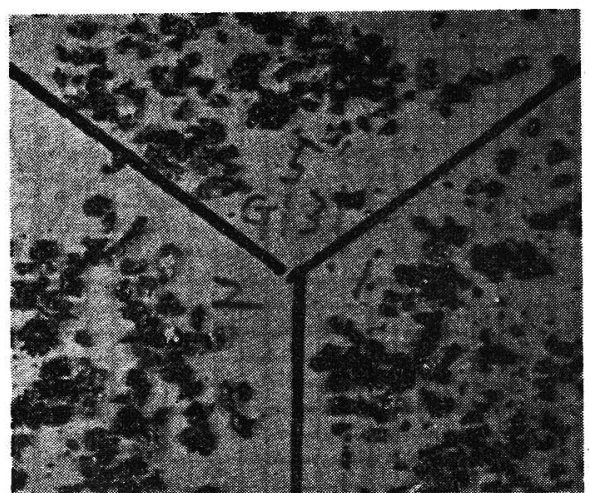

Chips of plain cast iron. $\times 3$

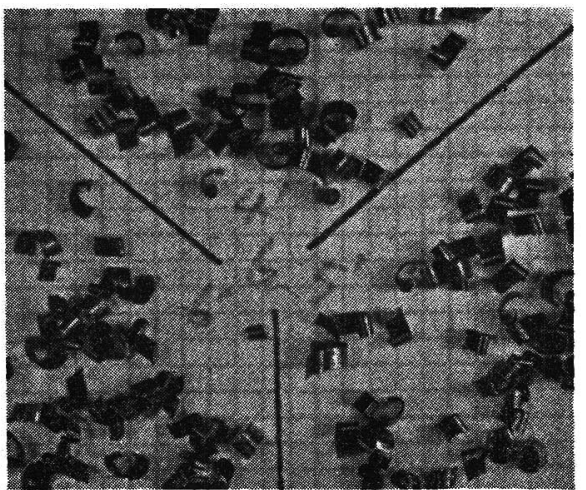

Chips of meehanite cast iron.

Photo. 2.

Table 2.

\begin{tabular}{|c|c|c|c|c|}
\hline $\begin{array}{l}\text { Kinds of } \\
\text { cemented } \\
\text { carbide } \\
\text { used }\end{array}$ & $\begin{array}{l}\text { Difference } \\
\text { of WC } \\
\text { grain size }\end{array}$ & $\underset{\text { Hardness }}{\mathrm{RA}}$ & $\begin{array}{c}\text { Transverse } \\
\text { rupture } \\
\text { strength } \\
\left(\mathrm{kg} / \mathrm{mm}^{2}\right)\end{array}$ & $\begin{array}{c}\text { Main } \\
\text { cutting } \\
\text { application }\end{array}$ \\
\hline G1 & Fine & $51 \cdot 8$ & 129 & $\begin{array}{l}\text { For } \\
\text { finishing } \\
\text { of cast } \\
\text { iron }\end{array}$ \\
\hline $\mathrm{G} 2$ & Coarse & $90 \cdot 2$ & 160 & $\begin{array}{l}\text { For } \\
\text { roughing } \\
\text { of cast } \\
\text { iron }\end{array}$ \\
\hline $\begin{array}{c}\text { C1 or C2 } \\
\text { due to the } \\
\text { designa- } \\
\text { tion of } \\
\text { U.S.A. } \\
\text { manufac- } \\
\text { tured by K } \\
\text { company }\end{array}$ & $\begin{array}{c}\text { Fine and } \\
\text { coarse } \\
\text { grains } \\
\text { are dis- } \\
\text { tributed } \\
\text { by half. }\end{array}$ & $90 \cdot 6$ & - & $\begin{array}{c}\text { For } \\
\text { general } \\
\text { purpose of } \\
\text { cast iron, } \\
\text { specially } \\
\text { for } \\
\text { roughing. }\end{array}$ \\
\hline
\end{tabular}

下で移動し工具自体に損傷を惹き起とすものと，切り 屑が工具すくに面上を高温，高压下に移動するをめ， 工具材質と切り屑が分子間凝着を惹き起とすととによ つて起とる接着現象の二つがある。この二つの損賃原 因によつて種々の損傷を発生するが，乙れらをらくつ かの基本的損㑺種類に分類するととができる。まず， 鋳鉄切削飞和々ては Photo. 3 亿示しそ矩形型チッピ ング, Photo. 4 亿示した流れ型チッピングの二つがあ げられる. 矩形型チッピングというのは, 主切为各部 で工具材質が均一飞細かくチッピングしそをめに外観 上矩形状を示すものであり，流れ型チッピングといら のは欠け落ちる粒は細からが，ノーズに近いほどチッ ピングの烈しかつたもので，外観上平滑な流れ状を示 す。並列した図は切刃のところとてろに局部的炕大を なチッピング，ななわち異常チッピングがそれぞれ前 二者併発したものである。この症か，切削上重要な 働ををなすノーズ部の損賃には Photo. 5, 6 のように 円弧状，直線状にチッピングするすのとの二つが分類 され，後者はチッピングが烈しいときに現われる。 ま そ，すくい面には切り属が接着する場合があるが，そ の接着の仕方に二つあり,その一つは単純に切り居が すくに面に接着し，他は切刃が小さく斜沉欠けて，こ
Table 3.

\begin{tabular}{|c|c|c|c|c|}
\hline No. & $\begin{array}{l}\text { Kinds } \\
\text { of } \\
\text { experi- } \\
\text { ment }\end{array}$ & $\begin{array}{c}\text { Cemented } \\
\text { carbides } \\
\text { used }\end{array}$ & $\begin{array}{c}\text { Cutting } \\
\text { conditions }^{* *}\end{array}$ & $\begin{array}{c}\text { Tool shape } \\
\text { by DIN } \\
768 \text {. Lapped } \\
\text { by } 320 \# \\
\text { Diamond } \\
\text { wheel }\end{array}$ \\
\hline 1 & $\begin{array}{c}\text { Tool } \\
\text { failure } \\
\text { and the } \\
\text { kinds of } \\
\text { cemented } \\
\text { carbide }\end{array}$ & $\begin{array}{l}\text { G } 1 \\
\text { G } 2 \\
\text { C } 2\end{array}$ & $\begin{array}{l}V=113,191,322 \\
d=0 \cdot 5 \\
f=0 \cdot 1,0.2\end{array}$ & $\begin{array}{l}5^{\circ}-85^{\circ}-0^{\circ}-45^{\circ}- \\
90^{\circ}-0^{\circ}-0 \mathrm{~mm}\end{array}$ \\
\hline $2^{*}$ & $\begin{array}{c}\text { Tool } \\
\text { failure } \\
\text { and feed }\end{array}$ & G 2 & $\begin{array}{l}V=152 \\
d=c \cdot 5 \\
f=0 \cdot 05,0 \cdot 1,0 \cdot 2\end{array}$ & " \\
\hline 3 & $\begin{array}{l}\text { Tool } \\
\text { failure and } \\
\text { depth of } \\
\text { cut }\end{array}$ & G 1 & $\begin{aligned} V= & 243 \\
d= & 0 \cdot 15,0 \cdot 2,0 \cdot 4 \\
& 0 \cdot 5,0 \cdot 75,1\end{aligned}$ & " \\
\hline 4 & $\begin{array}{l}\text { Tool } \\
\text { failure and } \\
\text { relief angle }\end{array}$ & G 1 & $\begin{array}{l}V=277 \\
d-1 \\
f=0.05\end{array}$ & $\begin{array}{l}\text { Same the } \\
\text { above except } \\
\text { relief and } \\
\text { wedge Angle. }\end{array}$ \\
\hline
\end{tabular}

Note, *: Use each newly ground tool corresponding to each cutting time to obtain the graph $V_{B}$-Time for estimating the repeatability of the abnormal chipping which often happens at the begining of cutting by the sharp cutting edge.

**: $V \sim$ Cutting speed in $\mathrm{m} / \mathrm{min}$ $d \sim$ Depth of cut in $\mathrm{mm}$ $f \sim$ Feed per revolution in $\mathrm{mm}$

***: DIN 768, for example, means respectively the following

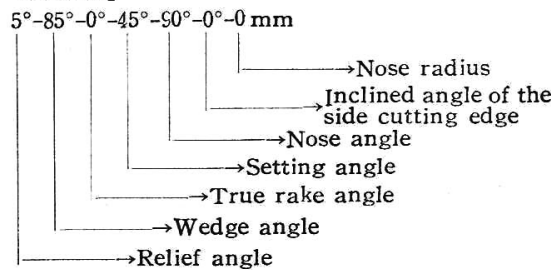

こに自由な流れを阻止され究切屑が加工硬化されて 堆積する場合で，後者は必すしも低々削り速度でばか りでなく高い削り速度でも起とる，以上，主にチッピ ングによるものをあげをが，接着によるもの，狭義に 
Type A

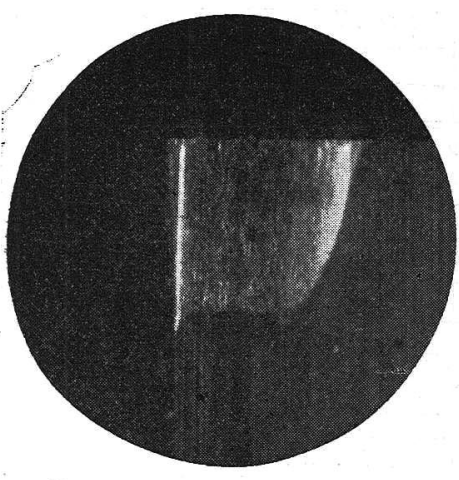

Rectangular flank wear land type.
" Type B

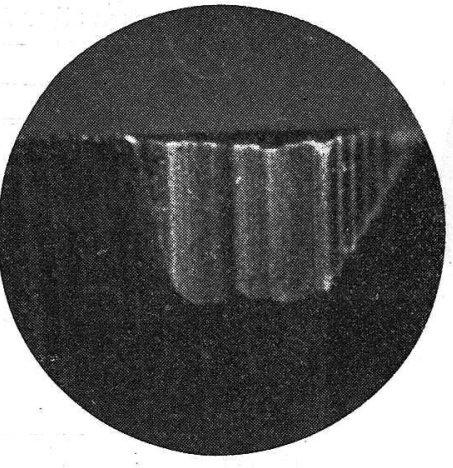

Rectangular flank wear land type with abnormal chipping.

Photo. 3.

Type C

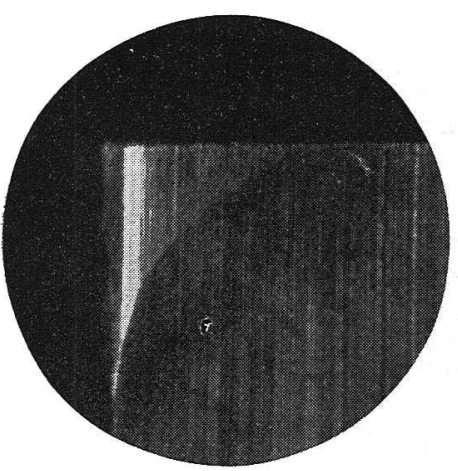

Triangular flank wear land type.

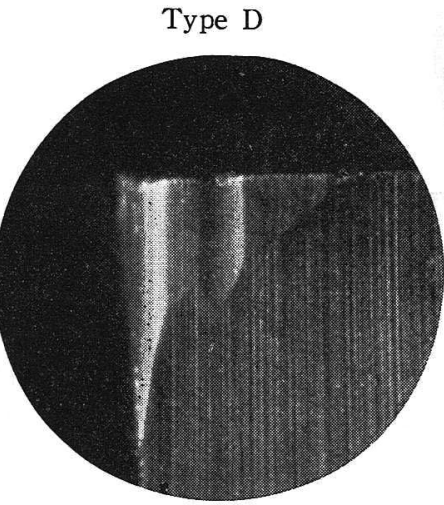

Triangular flank wear land type with abnormal chipping.

Photo. 4.

クレータといわれる典型例を Photo. 7 K示した. これは鋳 鉄切削に和々て最も一般的に 現われる無堤防クレータ型と して分類され，そのく深み面 は溶融状であつて, 高温のた め超硬合金材質の一部が溶け て切り原火溶着して小量和つ 規則的に持ち去られてでをな ものである. 切妇の部分には Photo. 8 の鋼切削飞見らる ような両堤防型之異なつて切 刃とく祭みの間壁がなく， くばみが次第に深さを增すと Type G

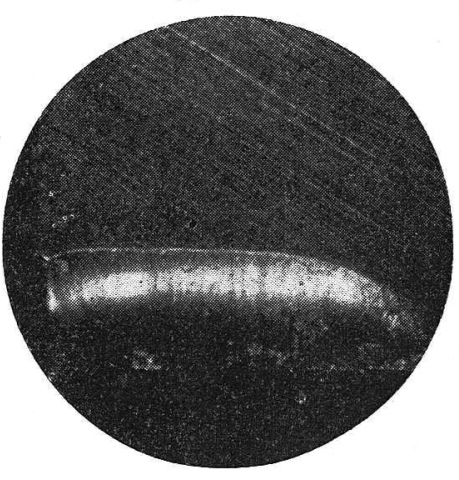

Crater type without land.

Photo. 7.
Type E

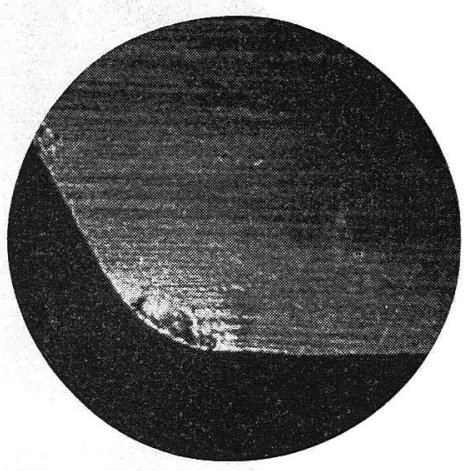

Round nose wear type.

Photo. 5.

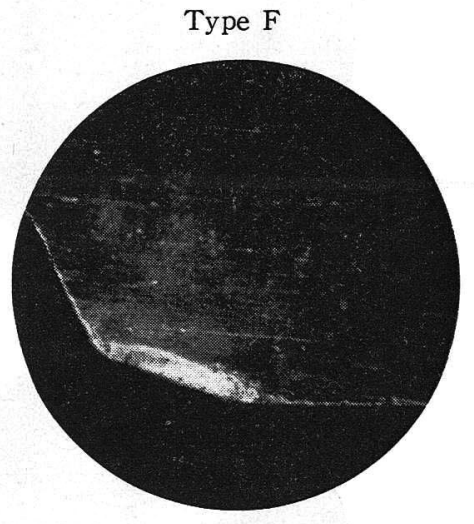

Linear nose wear type. Paoto. 6.

Type $\mathrm{H}$

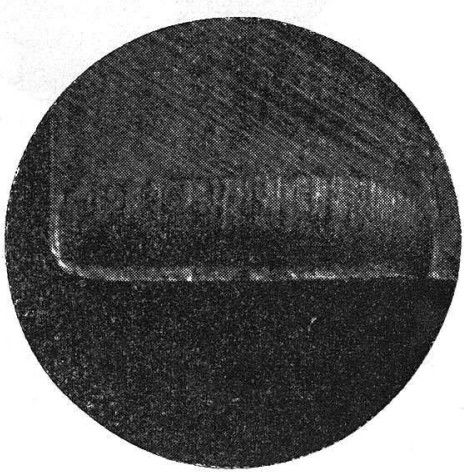

Crater type with each land.

Photo. 8.
刃先が鋭くなり, 部分的に異常チッピングして, やが て大規模な欠損を示すに至るすので, 抗張力の高い鋳 鉄を高速, 高送りで削つそとき現われるのが普通で ある. な叔, 銶鉄切削飞和々て堤防が現われ難的のは 鋳鉄の切くず分離が刃先近接部で行われる上に, 鋼切
削より相対的衝撃力の変化が烈しい前めに, 切刃のチ ッピングが速やが烈しく起とるからである。

$$
\text { 5. 実 驗 結 果 }
$$

（i）超硬合金材質と損傷

（a）削リ速度 $113 \mathrm{~m} / \mathrm{min}$ のとき 3 種の工具 


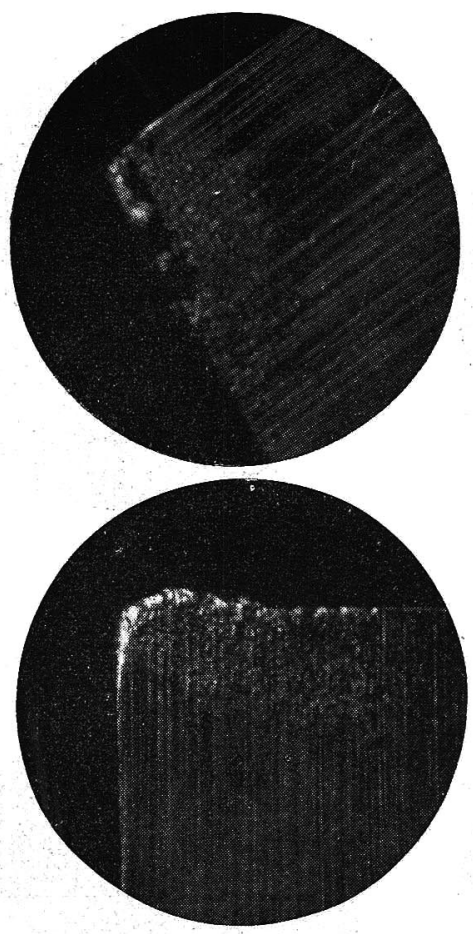

Photo. 9.

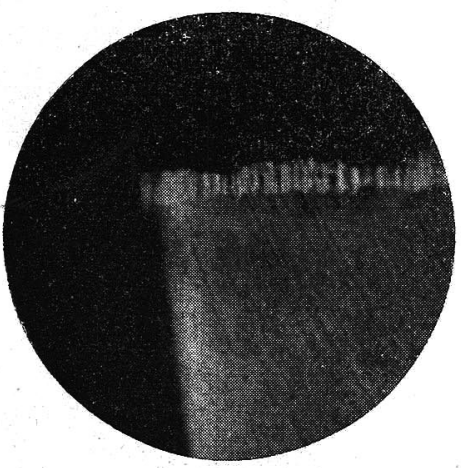

Photo. 10.

材質とも類似しを損傷で，その代表例を Photo. 9 K 示した。この因涀るように顕著な接着物の発生を見 るが，その高さは不同で不規則である。乙れは遊離黒 鉛を舍む切り属にようて形成される接着物が脆らとと， 工具材質との親和性が劣るため接着㬝が弱にとと，さ ら飞鋳鉄切削では为先湤內る相対的衝撃が, 鋼切削

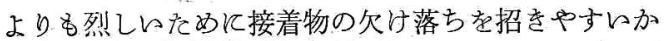
らである. 特に, ノ一゙の逃げ面損傷がにちじるしい のは，ノーズ部がもともと力学的に弱く異常チッピン グしやすん上に，接着物の久け落ちによりノーズ部の チッピングが促進されるかららでする. Photo. 10 は比 較用飞鋼切削飞和ける接着物発生例をあげてもので, 接着物が切刃部を覆つて長時間刃先赾保護したもので ある.Fig. 1 は各材質の損稘の時間的变化を示すをめ
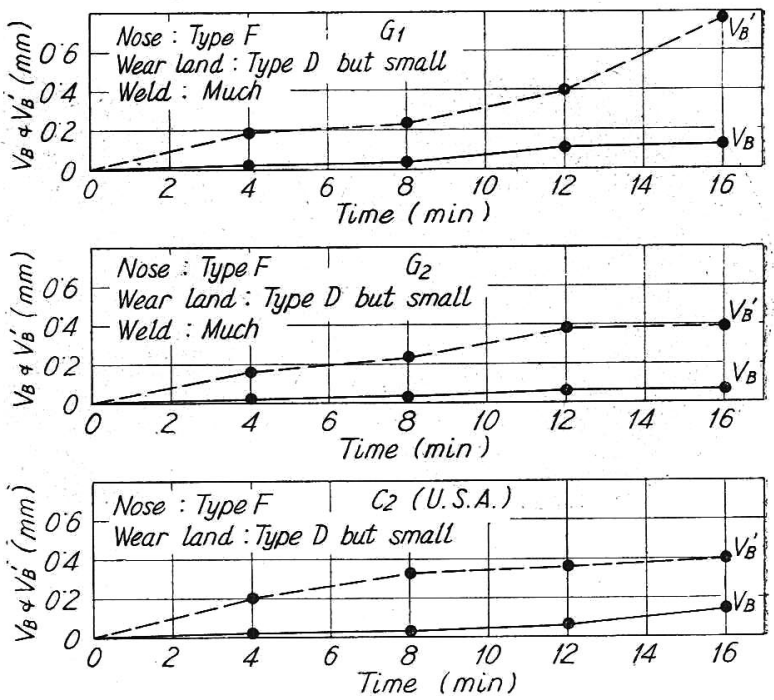

$$
\begin{aligned}
& V=113 \mathrm{~m} / \mathrm{min} \\
& f=0.1 \mathrm{~mm} / \mathrm{rev} . \\
& d=0.5 \mathrm{~mm}
\end{aligned}
$$

Fig .1.

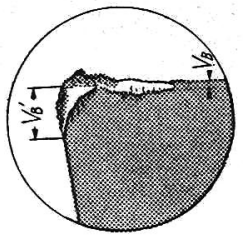

Fig. 2.

K, Fig. 2下飞記入しそ逃げ面の摩耗带平均幅 $V_{B}$ と， 一ズ部の摩耗幅 $V_{B}{ }^{\prime}$ を用的て表わしをもので,ささらに, そのとを観察されを椇賃種類をむPhoto. 3 よりPhoto.

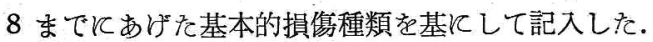

Fig. 1 とよれば $\mathrm{G}_{1}$ は脆いためとノーズの損傷量が多 く, K社品は比較的平滑尔損賃の時間的变化を示して 沾.

（b）削リ速度 $191 \mathrm{~m} / \mathrm{min}$ のとき 各材質の比 較をPhoto. 11 亿示した。 との条件では各材質の特異 性を明膫には識別できないが, 接着物の発生はよはど 少なくなつている。一方, 摩耗帯の発生がロらじるし ๖.これは削り速度の增大によつて冈先温度が上年し 切冈のチッピソグが促進される法か, 逃げ面が削つ沦 後の被切削材と接触して摩耗帯の増加が促進されるか らである．同図によれば， $\mathrm{G}_{1}$ では接着物が比較的多く 切刃が小さく欠けやすいととを示すほか, 摩耗帯がノ ーズに近的部分とをうでね部分との二つに分かれ， との材質が特にノーズ部で異常チッピングしやすいと とを示す. $G_{2}$ と $\mathrm{K}$ 社品は的和电単純に流れそ摩耗带 を示すが，K社品の方が接着物少なく流れ方が滑らか

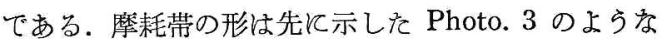


G 1

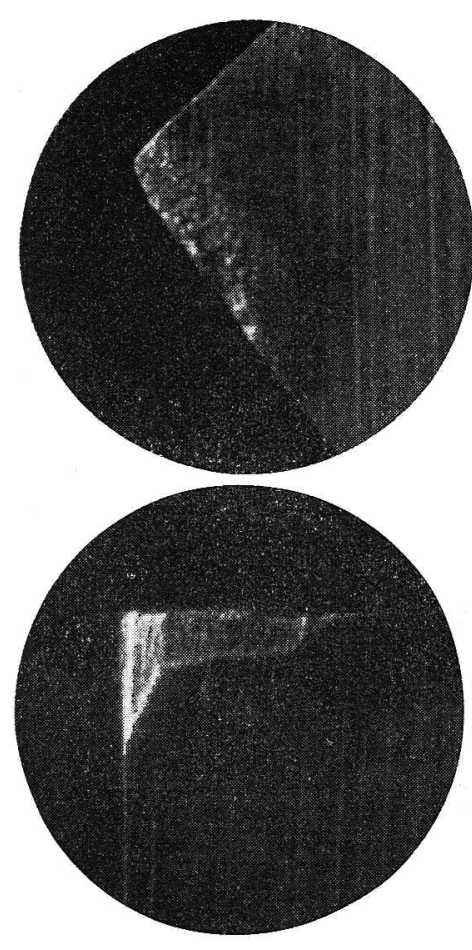

G 1

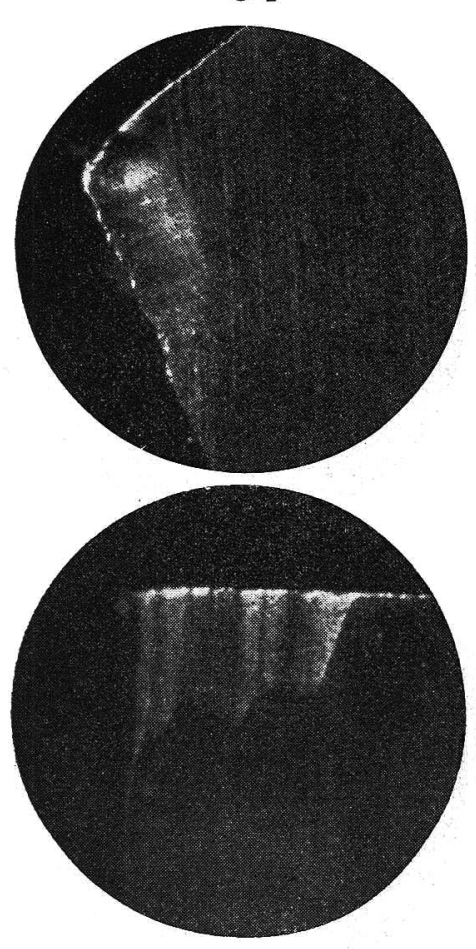

G 2

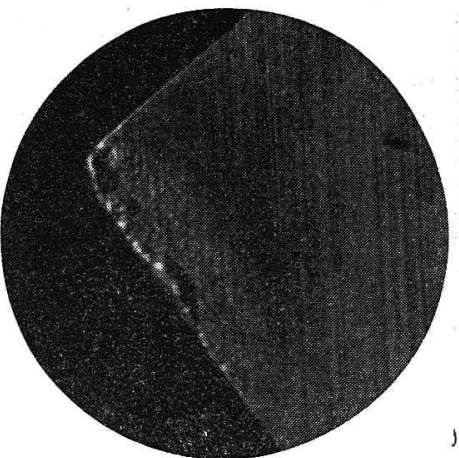

G 2

C 2 (U.S.A)

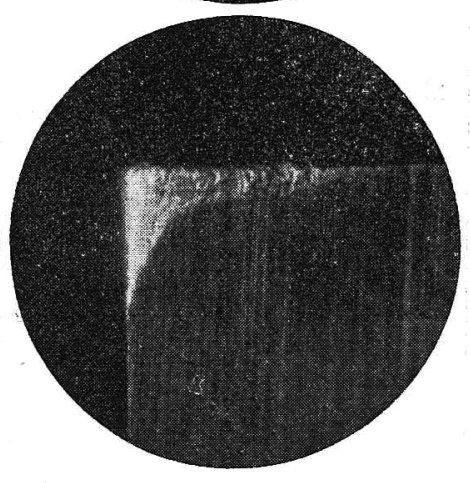

Photo. 11.

C 2 (U.S.A)
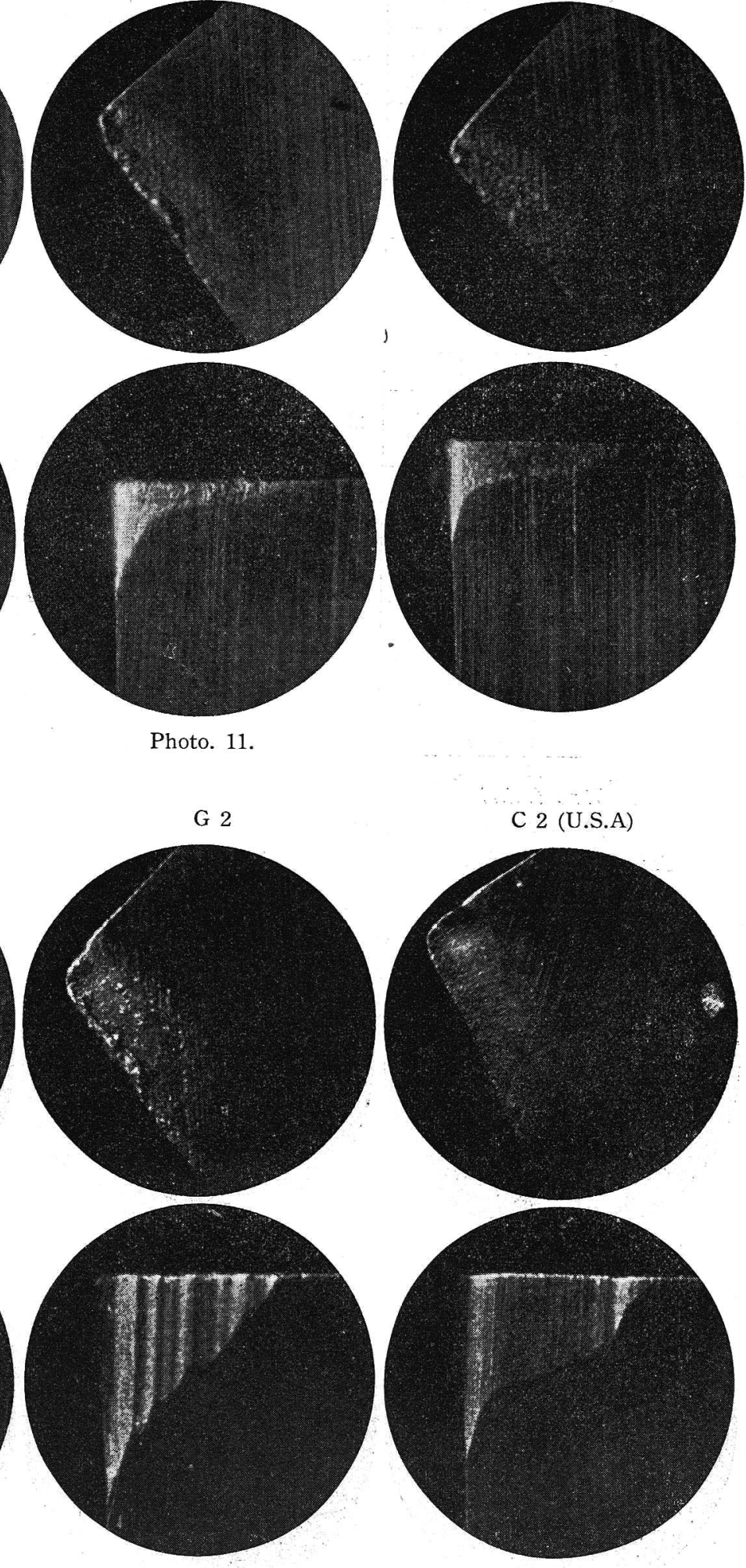

Photo. 12. 

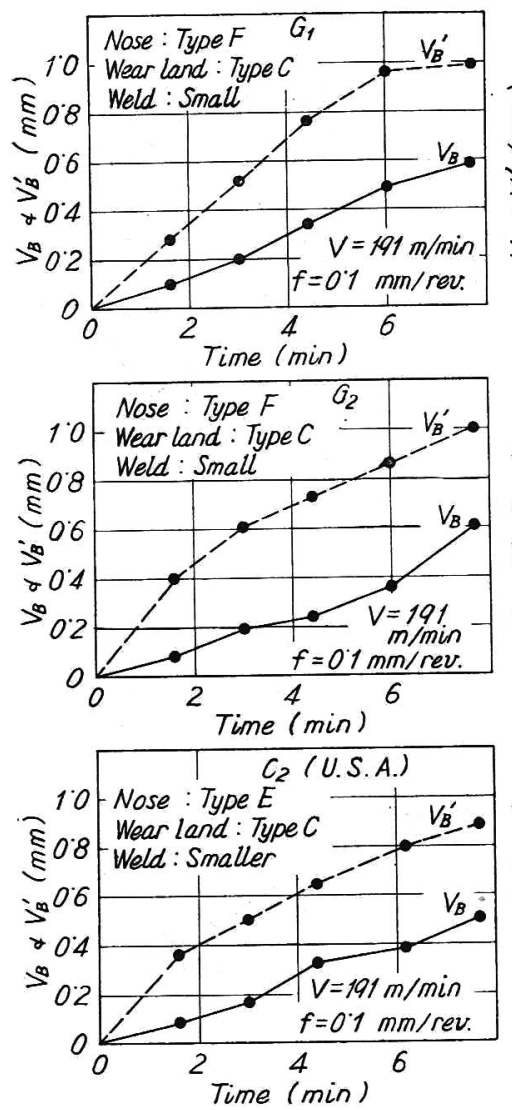

矩形型であるととが，被削材 の寸法精度, 工具の再研笔上 有利であるが，乙の被削材料

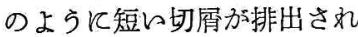
る場合には, 刃先温度や切削 压が特に不均一でノーズほE゙ 高らために，このよう火流れ そ形を示すものと推定され る。

(c) 削リ速度 $322 \mathrm{~m} / \mathrm{min}$ のとき 各材質の損稘比较 をPhoto. 12 亿示しそ. との 削り速度はこの実験に用的た ような顿質鋳鉄飞対しても可 成り高にため切削熱多く, 高 温下に和ける各材質の損稘上 の特異性を知ることがでを る. 同図《よれば $\mathrm{G}_{1}$ の䘭耗 帯は质矩形型であるが. 切 刃の異常チッピングによる条 溝が見られ，充，くばみ 深ら. $\mathrm{G}_{2}$ ではく度みは少な らが摩耗帯はらちじるしく流 れている上に多数の条溝を伴 々，接着物も認めら礼る。 K

Fig. 3.

Feed : $f=0 \cdot 05 \mathrm{~mm} / \mathrm{rev}$

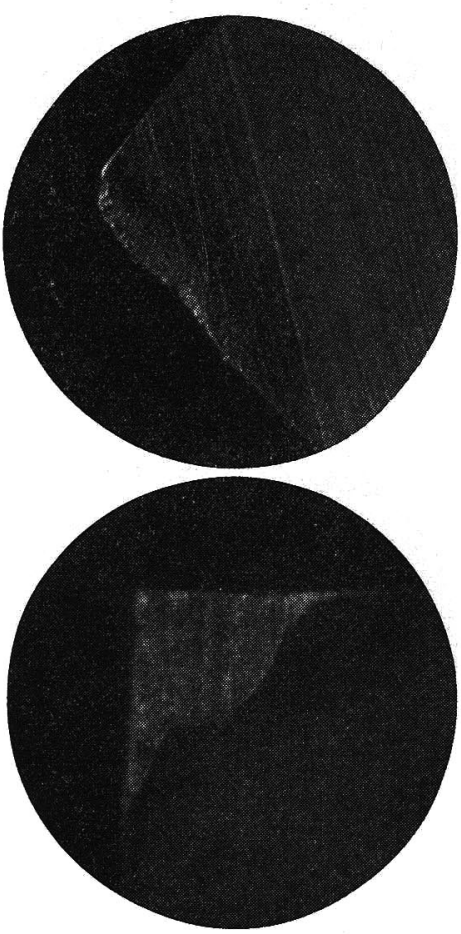

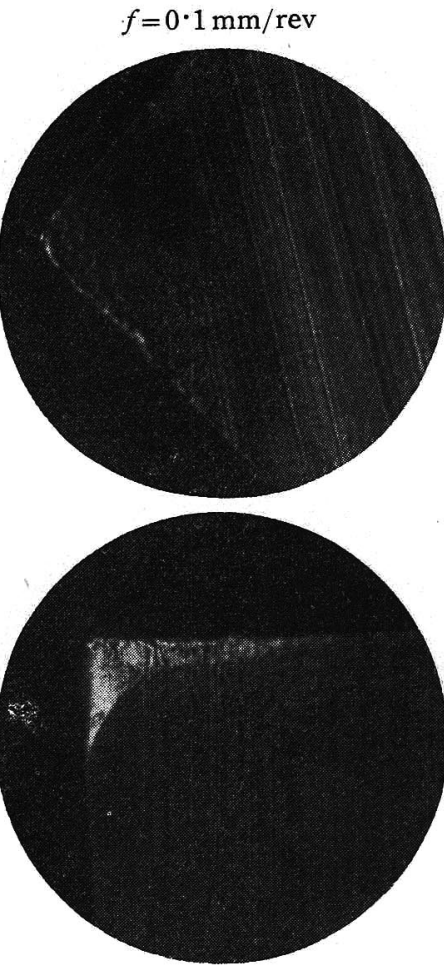

Photo. 13. $f=0.2 \mathrm{~mm} / \mathrm{rev}$

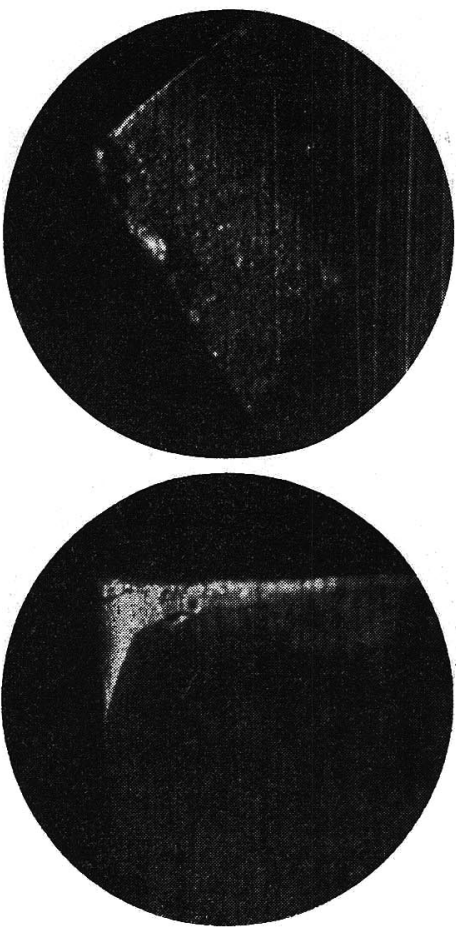



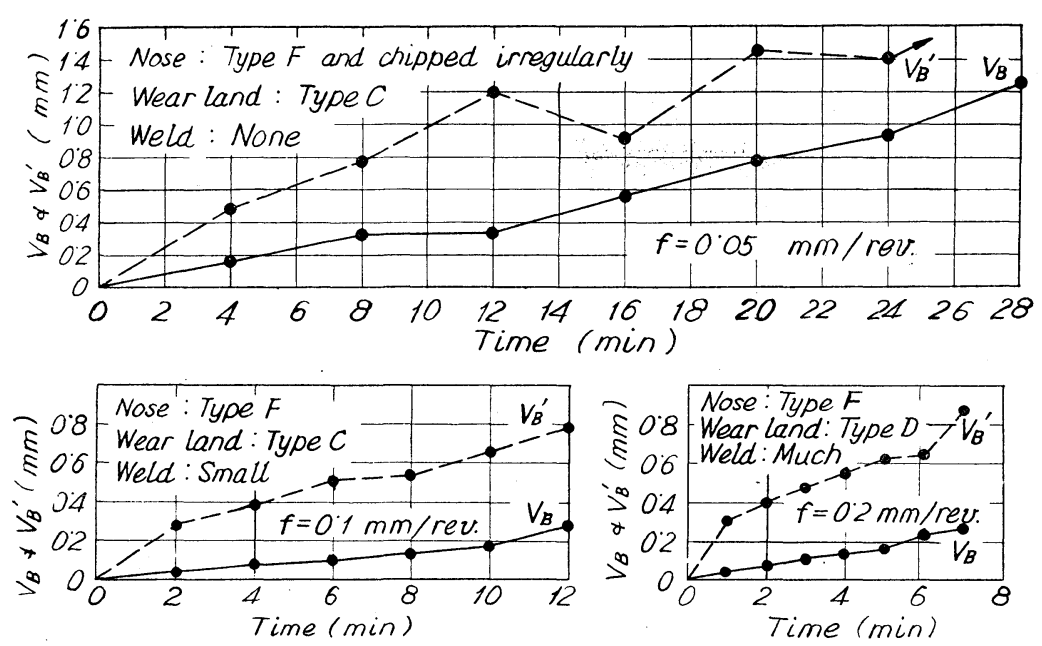

Fig. 4.
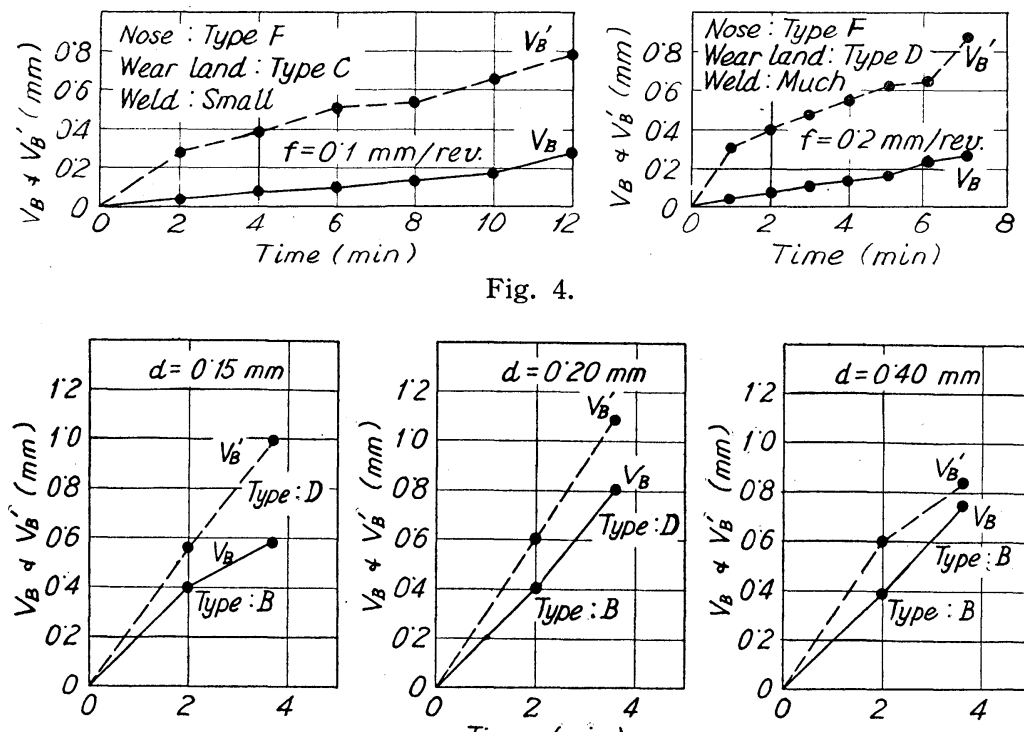

Time (min)

Time (min)
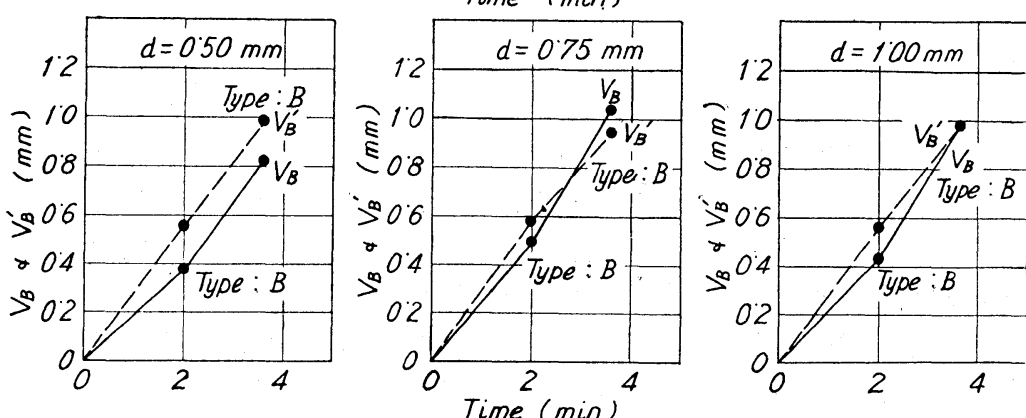

$G_{1}: V_{1}=243 \mathrm{~m} / \mathrm{min}, \quad f=0.05 \mathrm{~mm} / \mathrm{rev}$.

Fig. 5.

社品のく潘みや摩耗帯の形は $G_{1}, G_{2}$ の中間であるが 条溝少なく平滑である。このようなく深みの深さや摩 耗帯の形の相違は, 工具材質の粒子の大小ゃその分布 状況が影響しているものと見られ， $\mathrm{G}_{1}$ のような粒子の 細から材質は耐く将み摩耗性, すなわち, 㹨義の耐ク レータリング性化劣るが，摩耗帯は矩形型となる傾向 があり， $\mathrm{G}_{2}$ のように粒の粗い材質は耐クレータ性に すぐれているが，流れを摩耗帯となる，K社品はその 粒の分布状況が $\mathrm{G}_{1}$ 己 $\mathrm{G}_{2}$ の中間飞近いそめに，その 摩耗帯の流れ方が両者の中間であつたもので，〈ばみ

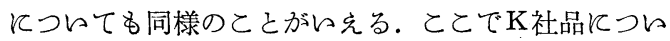
をととを表わしている。

(iii) 切込と損傷
て特に注目すべきは接着 物や異常チッピングの少 ないととで, $\mathrm{G}_{1}$ と $\mathrm{G}_{2}$ で 摩耗带の形が異索つてい るのは, その成分や用途 が異なる, す㞧わち, 超 硬合金の材種が異索つて らるためであるが, 几ず れの場合飞和々て子異常 チッピングの併発は好ま しくないのである。

Fig. 3 壮上述の両削り 速度の場合の $V_{B}, V_{B}^{\prime}$ の 時間的変化を示したもの で, 削り速度 $191 \mathrm{~m} / \mathrm{min}$ では K社品が， $322 \mathrm{~m} /$ min では $\mathrm{G}_{1}$ がよいが, 前述のよう飞損傷の種類 をも考慮すればK社品が との切削飞和々ては最子 好ましいものと的兊る。

\section{（ii）送少と損傷}

同一切削時間での各送 りとよる損賃の比校を Photo. 13 亿示した. と の場合, $\mathrm{G}_{2}$ を用的の で、ロずれも流れ型の奖 耗带を示すが，送り0.05 $\mathrm{mm} / \mathrm{rev}$ のものはきわめ て摩耗が多い.との理由 は送りが余り細からと刃 先の微細な衝撃が堌加す るとと, 切り屑が薄いた めに切削熱の外部への搬 出が少ないてめ, 特化摩 耗帯部の温度が高くなり， 切刃のチッピングが增加するをめと推定される。また， 送り $0.1 \mathrm{~mm} / \mathrm{rev}$ と $0.2 \mathrm{~mm} / \mathrm{rev}$ と索比校すると, 後 者の方が大をな衝撃力を与えるため切刃が小さく斜欠 けして，とこに大き接着物が出来やすいてとがわか る. Fig. 4 はこのときの損伤の時間的変化を示したも ので, 特に送り $0.05 \mathrm{~mm} / \mathrm{rev}$ の線図が不規則である ことは，ノーズ損傷が直線型であるとととあいまつて， ノーズの急速なチッピングや異常チッピングを起とし

Fig. 5 亿実験結果を示しそ。乙の実験では $\mathrm{G}_{1}$ を用 

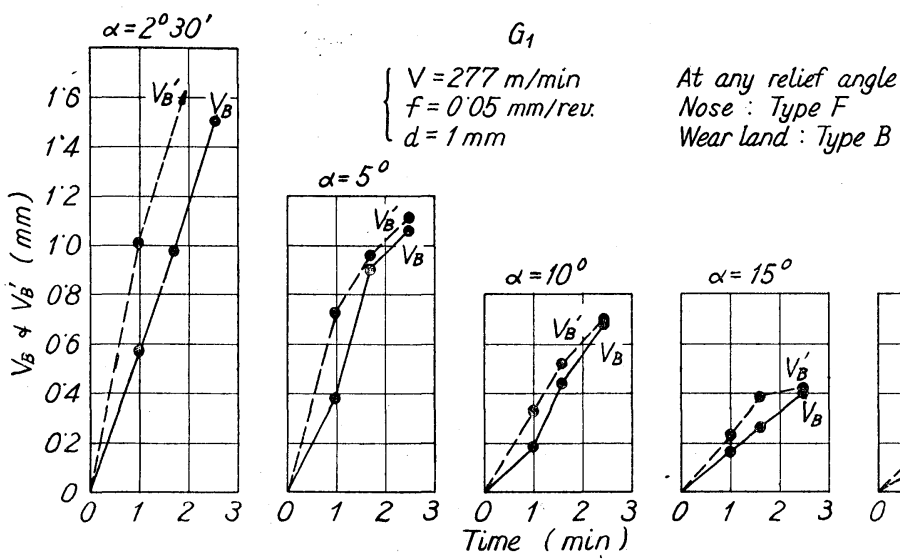

Fig. 6.

Table 4.

\begin{tabular}{c|c|c|c|c|c}
\hline Relief angle $\alpha$ & $2^{\circ} 30^{\prime \prime}$ & $5^{\circ}$ & $10^{\circ}$ & $15^{\circ}$ & $20^{\circ}$ \\
\hline $\begin{array}{c}V_{B} \text { measured at } \\
\text { the cutting } \\
\text { time of } 50^{\prime \prime}\end{array}$ & 0.58 & 0.38 & 0.19 & 0.18 & 0.11 \\
\hline$\Delta S \quad "$ & 0.025 & 0.033 & 0.034 & 0.048 & 0.640 \\
\hline $\begin{array}{c}\text { Ratio of } V_{B} \\
\text { attained from the } \\
\text { above dates }\end{array}$ & 5.27 & 3.46 & 1.73 & 1.64 & 1 \\
$\begin{array}{c}\text { The theoretical } \\
\text { ratio of } V_{B} \\
\text { attained from the } \\
\text { relation } \\
V_{B}=\Delta S \cdot \cot \alpha \\
\text { when } \Delta S \text { equals } \\
\text { at any relief } \\
\text { angle }\end{array}$ & 8.32 & 4.17 & 2.06 & 1.36 & 1 \\
\hline
\end{tabular}

らそので $0.2 \mathrm{~mm}$ 以下のような少ない切込では早く流 れ型となるが，そ礼以上では矩形型チッピングとなつ そ。 また, 切込 $0.4 \sim 1 \mathrm{~mm}$ の間では摩耗帯幅飞大差 のならとともわかつた。

\section{(iv) 逃け角之損傷}

Fig. 6 亿実験結果を示しそ。とのときには実験(iii) 之同様に $\mathrm{G}_{1}$ を用的たで矩形型の摩耗帯であるが, この図に見るよう沉逃げ角は摩耗帯幅の大小にいちじ るしい影響を与えている. とのととはFig. 7 の幾何学 的関係よりも予想されるが, Table 4 で検討しれよう 飞 $\Delta S$ がもし各逃げ角で同一であるならば，たと兊ば $\alpha=2^{\circ} 30^{\prime}$ と $20^{\circ}$ での $V_{B}$ の比は $8.32: 1$ 亿なるべを ところ, 実際には 5.27:1 となつている。すねわち, 逃げ角が多い质ぎ $\Delta S$ が多くなる傾向がある。しかし， 逃げ角を適宜大にして摩耗帯幅の增大を防止するとと は, 仕上切削飞和々て $\Delta S$ が加工品の寸法精度に重大 なる影響を与充，荒削り飞和々て切削初期の刃先強 度不足のため飞起とる久損を発生せぬ限り, 実用上の 工具寿命に対し効果が多的。

\section{6. 結}

\section{論}

超硬合金で鉱鉄を切削するとを，削り速度によつて 異なる損第種類が現われる。す多わち，低ら削り速度

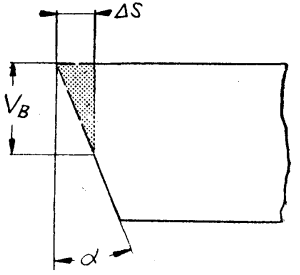

Fig. 7.

で注接着物が発生するが，と れはノーズの損㩐を異常に大 きくする理由の一つとなつて ロる。鋳鉄飞和斿る接着物は 不安定で欠け落ちやすりから である．削り速度が大きくな ると接着物の発生は少なくなるが，その代り摩耗帯は 增加する。摩耗带の形には矩形型と流れ型があり, $\mathrm{WC}$ 粒の細から材質は前者, 粗材質は後者の形をと りやすい，一方，クレータは粒子の細かけ方起とり やすレ．とのようと摩耗帯の形やクレータの発生傾向 は超硬合金の材質によつて異なるが，いずれの場合で も異常チッピングの併発は最も好をしくない. 実験に 用的を普通鋳鉄は硬さや抗張力が低く，乙か子小さな 孔があるため短切り屑を排出するととから，切削圧 や温度はノーズに近い后に゙高いすのと見られ，その上 小孔の影響も受けてノーズの相対的衝撃力が高らそめ, らすれの工具材質もさきれあげたような理想的な矩形 型チッピングやノーズ円弧型チッピングは現われなか つた。 しかし一方, Photo. 7 のような烈し的無堤防 クレータ型も現われす，したがつて，全く切削不能と なるような大規模な欠損も現われなかつた。 3 種の材 質中では $\mathrm{G}_{1}, \mathrm{G}_{2}$ の中間ぐららの性質の $\mathrm{K}$ 社品が異常 チッピングの少なら点で, ますこの種鋳鉄の切削に適 当しているといえる。しかし，その摩耗幅などの数量 的優位さはわすかであり，また常てK社品がよい性能 走示すとは，切削飞和的関与する因子の多々点より 容易汅予想するととはでをないが，との種の切削によ る材質試験に扣々ては, 摩耗量などの定量的比較と同 時に損傷種類の定性的観察も重要であるととが結論さ れる。

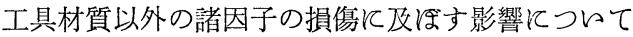
は, 特に逃げ角は摩耗帯幅関する限り可成り大をな 影響を与えるととぶわかつた。

洼: 一

1) 日本機械学会諭交集110号, 超硬工具の試騟法以関卞る研究（損 第の種類について), 奥自, 長富, 大草 